\title{
Occurrence and Growth Inhibitory Activity of Striga hermonthica (Delile) Benth on Sorghum bicolor (L.) Moench in Lafia, Nigeria
}

\author{
${ }^{*}$ G. F. Akomolafe, T. P. Terna and J. I. Okogbaa \\ Department of Botany, Federal University Lafia, PMB 146, Lafia, Nasarawa State, Nigeria \\ ["Corresponding Author: gfakomolafe@yahoo.com; : : +2348129069643]
}

\section{ABSTRACT}

Incidence of Striga hermonthica was investigated on some Sorghum bicolor farms in Lafia, Nigeria. Quadrant sampling technique was used and a total of six plots of size $10 \mathrm{~m} \times 10 \mathrm{~m}$ each were sampled randomly in three locations, namely; Shabu, Shendam Road and Makurdi Road in Lafia North, East and Central respectively. Incidence parameters such as the number of Striga and Sorghum, the height of Striga, distance of Striga to infected Sorghum and height of Sorghum were documented. A total of 572 stands of Striga were counted in all sampled locations. Sorghum farms in Shabu had the highest mean population of Striga (261), followed by both Shendam and Makurdi Road with mean populations of 13 Striga each. Negative correlations were observed between height of Striga and height of infected Sorghum (-0.371), as well as between number of Striga and number of Sorghum plants $(-0.818)$. Distance of Striga to infected Sorghum correlated positively with height of infected Sorghum (0.153). Positive correlation was also observed between number of Striga and height of infected Sorghum (0.584). It was thus concluded that Striga had a significant negative effect on growth of Sorghum in the study area. Therefore this activity of Striga require integrated management approaches for sustainable Sorghum production and yield improvement.

Keywords: Incidence, Lafia, Parasitic activity, Striga, Sorghum

\section{INTRODUCTION}

Parasitic plants are among the most economically important pests of agricultural crops worldwide. Effective control measures are generally unavailable partly because of the close physiological connection between the established parasite and host plant hindering effective control using traditional methods (Gressel et al., 2004; Rispail et al., 2007, Runyon et al., 2009).

Striga hermonthica belonging to the group of plants considered as hemi-parasitic has constituted a major constraint to crop production worldwide. They obtain some or all of their nutrient requirements from infected crop plants (Kuijt, 1969; Parker and Riches, 1993; Musselman et al., 2001; Nickrent, 2007). Cereals such as maize, millet, Sorghum and sugar cane have been identified as common hosts of most Striga species (Musselman, 1980). In subSaharan Africa, farmers have reported losses between $20 \%$ and $80 \%$, and are eventually forced to abandon highly infested fields (Atera et al., 2011)

Striga has been reported to produce some germination stimulants called strigolactones which usually occur in amounts sufficient to stimulate its germination in a few meters from the roots of the host (Fate et al., 1990; Bouwmeester et al., 2007). This plant may also grow directly on the host roots depending on the concentration gradients of these strigolactones (Dube and Olivier, 2001). Knowledge of parasite-host interactions is required to facilitate the development of novel management approaches to crop infection by Striga (Runyon et al., 2009).

This study was carried out to evaluate the incidence of Striga hermonthica in some Sorghum bicolor farms in Lafia, in an effort to facilitate current efforts aimed at crop disease management and yield improvement in the study area. 
Table 2: Growth responses of S. bicolor to Infestation by Striga hermonthica on Farms in Lafia.

\begin{tabular}{|c|c|c|c|c|c|}
\hline Location & $\begin{array}{l}\text { Number of } \\
\text { guinea corn }\end{array}$ & $\begin{array}{l}\text { Distance of } \\
\text { Striga to } \\
\text { infested guinea } \\
\text { corn }(\mathrm{m})\end{array}$ & $\begin{array}{l}\text { Height of } \\
\text { Striga (m) }\end{array}$ & $\begin{array}{l}\text { Height of } \\
\text { infested guinea } \\
\text { corn }(\mathrm{m})\end{array}$ & $\begin{array}{l}\text { Height of } \\
\text { healthy guinea } \\
\text { corn (m) }\end{array}$ \\
\hline$A$ & $49.00^{c} \pm 2.50$ & $0.37^{b} \pm 0.02$ & $0.45^{c} \pm 0.02$ & $2.33^{a} \pm 0.45$ & $3.54^{b} \pm 0.50$ \\
\hline$B$ & $72.00^{a} \pm 6.00$ & $0.19 c \pm 0.04$ & $0.67^{a} \pm 0.07$ & $2.18^{a} \pm 0.12$ & $3.77^{b} \pm 0.15$ \\
\hline C & $64.00^{b} \pm 3.50$ & $0.42^{\mathrm{a}} \pm 0.09$ & $0.51^{b} \pm 0.02$ & $1.88^{b} \pm 0.19$ & $4.41^{\mathrm{a}} \pm 0.17$ \\
\hline \multicolumn{6}{|c|}{$\begin{array}{l}\text { Means followed by same superscripts within same column are not significantly different }(P \leq 0.05) \\
\text { A = Sampling location in Shabu; B = Sampling location in Shendam Road; C = Sampling location in Makurdi Road }\end{array}$} \\
\hline & & $\begin{array}{l}\text { Height of infested } \\
\text { guinea corn }\end{array}$ & \multicolumn{2}{|c|}{$\begin{array}{l}\text { Height of healthy } \\
\text { guinea corn }\end{array}$} & $\begin{array}{l}\text { Number of guinea } \\
\text { corn }\end{array}$ \\
\hline \multicolumn{2}{|c|}{$\begin{array}{l}\text { Distance of Striga to } \\
\text { infested guinea corn }\end{array}$} & 0.153 & 0.218 & \multicolumn{2}{|c|}{-0.306} \\
\hline \multicolumn{2}{|c|}{ Height of Striga } & -2.39 & -0.15 & \multicolumn{2}{|l|}{0.628} \\
\hline \multicolumn{2}{|c|}{ Number of Striga } & 0.584 & -0.371 & \multicolumn{2}{|c|}{-0.818} \\
\hline
\end{tabular}

There was increase in population of Striga with resultant decrease in population of Sorghum (Figure 1).

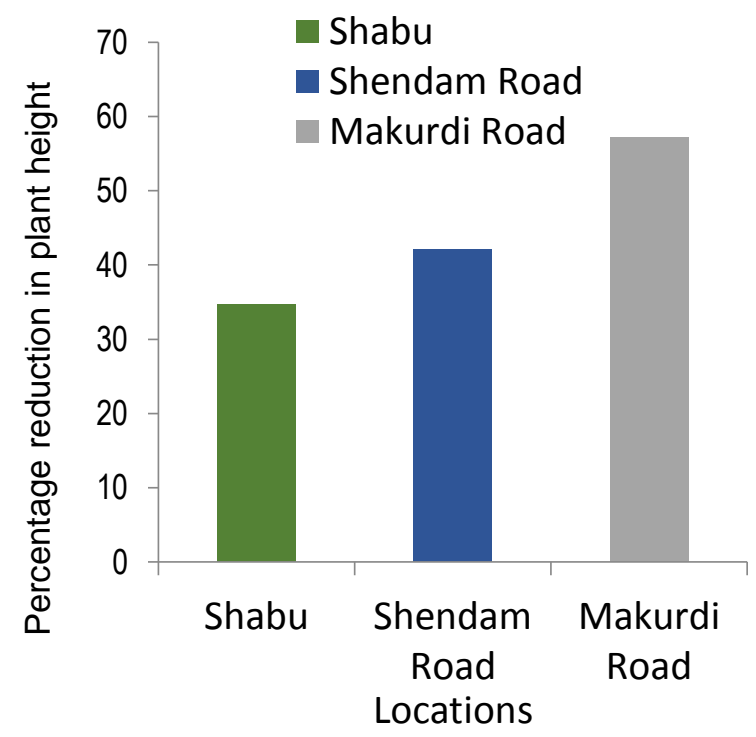

Figure 1: Percentage Reduction In Height of Infested Guinea Corn In Studied Locations

\section{DISCUSSION}

Shabu is known for abundance of dry sandy soil which supports growth of cereals and provides an ideal habitat for Striga to thrive, which accounts for the comparatively higher population of Striga in Shabu compared to other sampled locations. This is supported by CABI (2017), who also maintained that most of the agriculturally important Striga species favour relatively dry, infertile, especially low nitrogen, low phosphorus soil conditions and are typically problems in the semi-arid tropics of Africa and Asia.

The growth behavior of Striga observed in the study also agrees with reports by Ramaiah et al. (1983) who stated that Striga are erect herb reaching a height of $0.5 \mathrm{~m}$. Moreso, in a similar work by Rodenburg et al. (2006), it was reported that higher seedbank density resulted in more Striga plants, which led to increased intra-specific competition and consequently a reduced level of reproduction per plant. This also explains the decrease in Sorghum height with increase in Striga populations observed in the study. Westerman et al. (2016) also reported a strong intraspecific competition in populations of $S$. 
hermonthica which was most intense during the holoparasitic phase.

The reduction in height of infected Sorghum by parasitic activity of Striga could be attributed to loss of nutrients by infected plants as well as the possibility of the disruption of normal physiological activity in the host plant by the hemi-parasite. Reports by Ramiah et al. (1983) also established that the effect of Striga on the host, is more than just the removal of water, assimilates, and other nutrients, but also involves the stimulation of reduced production of growth promoters with the concurrent increase in production of growth inhibitors in host plants. Studies by Ast (2006) also reported increased levels of abscisic acid and decreased levels of cytokinins and gibberellins in infected plants. Recent studies by Traore (2016) in Ghana also reported that Sorghum progenies under Striga infestation showed reduced plant height, flowering, panicle length, and grain yield.

The increase in population of Striga with resultant decrease in population of Sorghum observed in the study could also be attributed to the myriad of virulence mechanisms adopted by Striga for successful parasitism on infected plants. Sand (1990) also stated that reduction in population sizes of host plants was typical of Striga infections. Striga seeds are known to germinate only in the presence of chemical stimulants released from plant roots (Runyon et al., 2009). It is therefore likely that closeness to the roots of host plants could mean greater availability of nutrients and enhanced parasitic activity on host plants by Striga spp.

\section{CONCLUSION}

Growth reduction and the consequent loss of Sorghum yield as a result of infestation and parasitic activity of Striga as observed in this study require integrated management approaches for sustainable Sorghum production and yield improvement in the study area.

\section{REFERENCES}

Ast, A.V. (2006). The influence of time and severity of Striga infection on the Sorghum bicolor Striga hermonthica association. Wageningen, Netherlands: Tropical resource management papers. Pp. 77.

Atera, E., and Itoh, K. (2011). Evaluation of ecologies and severity of Striga weed on rice in sub-Saharan Africa. Agriculture and Biology Journal of North America, 2(5): 752-760.

Bouwmeester, H.J., Roux, C., Lopez-Raez, J.A. and Becard, G. (2007). Rhizosphere communication of plants, parasitic plants and AM fungi.Trends in Plant Science, 12:224-230.

CABI (2017). Invasive Species Compendium. Available online at: http://www.cabi.org/isc/search/?q=\&types $=26 \&$ rows $=10 \&$ sort=DateDesc .Accessed: $11 / 5 / 2017$.

Carsky, R. J., Berner, D. K., Oyewole, B. D., Dashiell, K. and Schulz, S. (2000). Reduction of Striga hermonthica parasitism on maize using soybean rotation. International Journal of Pest Management, 46(2): 115-120.

Dube, M.P. and Olivier, A. (2001). Striga gesnerioides and its host, cowpea: Interaction and methods of control. Canadian Journal of Botany, 79: 12251240.

Fate, G., Chang, M. and Lynn, D.G. (1990). Control of germination inStriga asiatica: Chemistry of spatial definition. Plant Physiology, 93: 201-207.

Gressel, J., Hanafi, A., Head, G., Marasas, W., Babatunde, O.A., Ochanda, J., Souissi, T. and Tzotzos, G. (2004). Major heretofore intractable biotic constraints to African food security that may be amenable to novel biotechnological solutions. Crop Protection, 23: 661-689.

Kuijt, J. (1969). The Biology of Parasitic Flowering Plants, University of California Press, Berkeley. 


\section{Nigerian Journal of Basic and Applied Science (June, 2018), 26(1): 65-69}

Maps-StreetView.com (2011). Lafia Maps - road map, satellite view and street view. Available online at: https://www.mapsstreetview.com/Nigeria/Lafia/. Accessed: $11 / 5 / 2017$.

Musselman, L. J. (1980). The biology of Striga orobanche and other root-parasitic weeds. Annual Review of Phytopathology,18:463489.

Musselman, L.J., Yoder, J.I. and Westwood, J.H. (2001). Parasitic plants major problem of food crops. Science, 293: 1434.

Nickrent, D.L. (2007). Parasitic plant genera and species. Parasitic plant connection,http://www.parasiticplants.siu.e $\mathrm{dul}$.

Parker, C. and Riches, C.R. (1993). Parasitic Weeds of the World: Biology and Control, CAB International, Wallingford, UK.

Ramaiah, K.V., Parker, C., Vasudeva Rao, M.J., and Musselman, L.J. (1983). Striga Identification and Control Handbook. Information Bulletin No. 15. Patancheru, A.P., India: International Crops Research Institute for the Semi -Arid Tropics. Pp. 1-50.

Ramaiah, K.V. (1991). Breeding for Striga resistance in Sorghum and Millet In: Combating Striga in Africa. Kim, S.K. (Ed.). Proceedings of International Workshop on Striga, August 22-24, 1991 IITA, Ibadan, Nigeria, 75-89.

Ransom, J.K., Odhiambo, G.D., Eplee, R.E. and Diallo, A.O. (1996). Estimates from field studies of the phytotoxic effects of Striga spp. on Maize. In: Advances in parasitic plant research. Moreno, M.T., Curebo, J.I., Berner, D., Joel, D., Moselam, L.J. and Parker, C. (Eds.) Proceedings, sixth International Parasitic Weed symposium, April, 16-18, 1996 Cordoba, 328-333.

Rispail, N., Dita, M.A., Gonźalez-Verdejo, C., Perez-de-Luque, A., Castillejo, M.A., Prats, E., Roman,B., Jorrın, J. and Rubiales, D. (2007). Plant resistance to parasitic plants: molecular approaches to anoldfoe. New Phytology, 173: 703-712.

Rodenburg, J., Bastiaans, L., Kropff, M.J., and Ast, A. V. (2006). Effects of host plant genotype and seed bank density on Striga reproduction. AGRIS: International Information System for the Agricultural Science and Technology. Available online at: $\quad$ http://agris.fao.org/agrissearch/search.do?recordID=US201301081 469. Accessed: 11/5/2017.

Runyon, J.B., Tooker, J.F., Mescher, M.C., and De Moraes, C.M. (2009). Parasitic Plants in Agriculture: Chemical Ecology of Germination and Host-Plant Location as Targets for Sustainable Control: A Review. Sustainable Agriculture Reviews, 1: 1-131.

Sand, P., Robert, E., and Randy, W. (1990). Witchweed research and control in the United States. Champaign, IL: Weed Science Society of America. Pp. 89.

Showemimo, F.A. (2010). Effect of Striga hermonthica on yield and yield component of Sorghum in Northern Guinea Savanna of Nigeria. Journal of Plant Sciences, 5(1): 86-90.

Teka, H.B. (2014). Advanced research on Striga control: A review. African Journal of Plant Sciences, 8(11): 492-506.

Terna, T.P., Odebode, A.C. and Bem, A.A. (2013). Growth Suppression of Some Common Post-Harvest Rot Fungi By Culture Filtrates of A Soil Isolate of Trichoderma viride. IOSR Journal of Environmental Science, Toxicology and Food Technology, 3(3): 9095.

Traore, I. (2016). Evaluation of sorghum (Sorghum bicolor) varieties for resistance to striga (striga hermonthica) in Northern Guinea Savanna of Ghana. Kwame Nkrumah University of Science and Technology, Kumasi Ghana (Doctoral dissertation, published). Pp. 87

Westerman, P.R., Hemerik, L., Van der Werf, W., Stomph, T., Van Mourik, T.A. (2016). Competition in populations of the hemiparasitic plant Striga hermonthica on a Sorghum host. Julius-Kuhn-Archive, 452 : 100. 